\title{
Peran Regulasi Emosi terhadap Resiliensi pada Siswa Sekolah Berasrama Berbasis Semi Militer
}

\author{
Ayasafira Sukmaningpraja ${ }^{1}$, Fauzan Heru Santhoso ${ }^{2}$ \\ Fakultas Psikologi Universitas Gadjah Mada
}

\begin{abstract}
The purpose of this study was to determine the role of emotional regulation on resilience in boarding school students based on semi military. This research uses simple linear regression method.. Measuring instrument used was a questionnaire consisting of two scales : scale of resilience (Reivich \& Shatte, 2002) and the scale of emotional regulation (Thompson, 1994). Sample of the study was 90 persons $(N=90)$ which is a mixture of male and female students of boarding senior high school " $\mathrm{X}$ " in Magelang. The results of this study indicate that the the results of this study indicate that the regression coefficient of 0.665 and $R^{2}$ of 0.466 . These results show that emotional regulation plays a role in resilience of $46.6 \%$. So it can be concluded that emotional regulation plays a role in resilience in boarding senior high school "X" students based on semi military.
\end{abstract}

Keywords: boarding school, emotional regulation, resilience

\begin{abstract}
Abstrak. Tujuan dari penelitian ini adalah untuk mengetahui peran regulasi emosi terhadap resiliensi pada siswa sekolah berasrama berbasis semi militer. Penelitian ini menggunakan metode analisis regresi linier sederhana. Adapun alat ukur yang digunakan adalah kuesioner yang terdiri dari dua skala, yaitu skala resiliensi (Reivich \& Shatte, 2002) dan skala regulasi emosi (Thompson, 1994). Subjek dalam penelitian ini berjumlah 90 orang $(\mathrm{N}=90)$ yang merupakan campuran siswa putra dan siswi putri

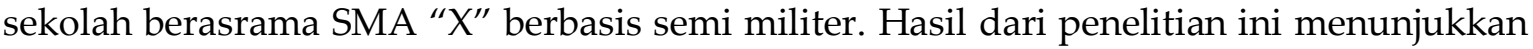
bahwa koefisien regresi sebesar 0,665 dan $\mathrm{R}^{2}$ sebesar 0,466. Hasil tersebut menunjukkan bahwa regulasi emosi berperan terhadap resiliensi sebesar 46,6\%. Sehingga dapat disimpulkan bahwa regulasi emosi berperan terhadap resiliensi pada siswa sekolah berasrama SMA “ $X$ " berbasis semi militer.
\end{abstract}

Kata kunci: regulasi emosi, resiliensi, sekolah berasrama

Salah satu cara dalam menciptakan suatu bangsa yang maju dalam berbagai aspek adalah melalui generasi penerus bangsa. Generasi penerus bangsa kita tentu saja merupakan generasi muda. Generasi muda merupakan generasi penerus bangsa yang nantinya akan meneruskan

\footnotetext{
${ }^{1}$ Korespondensi mengenai isi artikel ini dapat dilakukan melalui ayasafira.sukmaningpraja@mail.ugm.ac.id

2 Atau melalui fauzan@ugm.ac.id
}

estafet kepemimpinan dan membangun negeri ini di masa yang akan datang. Suatu bangsa harus dapat mencetak generasi muda yang berpendidikan serta memiliki jiwa kebangsaan yang tinggi.

Menurut Undang-Undang Republik Indonesia No. 20 Tahun 2003 tentang Sistem Pendidikan Nasional, ada 3 jalur pendidikan yang dapat ditempuh yang terdiri atas pendidikan formal, nonformal, dan informal agar dapat mencapai tujuan 
pendidikan. Dalam hal ini peneliti berfokus pada pendidikan formal khusunya pendidikan menengah yaitu Sekolah Menengah Atas (SMA).

Dewasa ini, fenomena Sekolah Menengah Atas (SMA) yang berasrama di Indonesia semakin meluas. Menurut Arsy (dalam Ulfiani, 2012) sekolah berasrama adalah sekolah dimana para siswa, guru, serta pengelola sekolah tinggal pada satu lingkungan yang sama yaitu di asrama dalam kurun waktu tertentu biasanya satu semester diselingi dengan berlibur dan akan terus tinggal bersama sampai menamatkan sekolahnya.

Salah satu sekolah berasrama di Indonesia pada jenjang Sekolah Menengah Atas (SMA) yaitu SMA " $X$ " berada di Jawa Tengah tepatnya di Magelang. SMA " $X$ " adalah sekolah menengah atas yang dicetuskan oleh menteri pertahanan dan keamanan pada tahun 1985 dengan berbasis semi-militer. Sekolah berasrama SMA "X" di Magelang menanamkan pendidikan yang menekankan pada nilainilai kejuangan, kebangsaan, dan kebudayaan yang dituangkan ke dalam aspek prestasi akademik, kesamaptaan jasmani, dan kemandirian. Para siswa sekolah berasrama SMA " $X$ " di Magelang dituntut untuk mengikuti serangkaian kegiatan selama 24 jam serta mematuhi semua norma yang berlaku di sekolah. Dalam sekolah berasrama SMA " $X$ " di Magelang para siswa juga diajarkan untuk hidup mandiri dan dapat bertahan menghadapi tekanan, karena sekolah berasrama ini sendiri merupakan sekolah yang bersifat senioritas dimana adik kelas selain harus menghormati guru tetapi juga harus menghormati kakak kelas.

Sekolah berasrama SMA " $X$ " yang sudah secara paten menerapkan peraturan seperti yang sudah disebutkan di atas tentunya membuat para siswa harus dapat beradaptasi dengan baik pada segala bentuk peraturan sekolah yang berlaku dan juga harus dapat beradaptasi dengan budaya yang berlaku di SMA " $X$ ". Hal ini lah yang akhirnya menimbulkan masalah pada siswa khususnya adalah masalah pribadi pada siswa.

Apabila siswa pada sekolah berasrama mengalami tekanan dimana hal tersebut akan membawa gangguan fisik serta emosional sampai timbul adanya trauma tentunya akan sangat mengganggu kegiatan belajar serta kegiatan sehari-hari siswa karena para siswa harus menjalankan aktivitas di dalam asrama selama 24 jam penuh. Efek lain yang timbul adalah seperti yang sudah dijelaskan diatas yaitu siswa merasa tidak kuat hingga trauma dan tidak mau sekolah lagi di tempat yang sama dan akhirnya pindah sekolah. Siswa seharusnya mampu bangkit dari trauma apabila siswa mempunyai resiliensi yang baik.

Menurut Reivich dan Shatte (dalam Nasution, 2011) individu mampu bangkit dari trauma yang mereka hadapi apabila memiliki resiliensi yang baik. Mereka belajar bahwa kegagalan bukanlah akhir dan mereka justru mencari pengalaman baru yang lebih menantang bagi hidup mereka karena sesuatu yang menantang akan membuat mereka berjuang keras untuk melewatinya dan dari proses itu mereka akan belajar serta dapat menambah wawasan mereka. Mereka memandang kegagalan itu sebagai sebuah pembelajaran yang bermakna untuk kehidupan selanjutnya.

Pada dasarnya setiap orang memiliki kemampuan untuk sanggup menghadapi setiap kesulitan di dalam hidupnya. Karena setiap orang itu pasti mengalami kesulitan ataupun sebuah masalah dan tidak ada seseorang yang hidup di dunia tanpa suatu masalah ataupun kesulitan. Kesanggupan menghadapi kesulitan itu 
akan semakin memperkuat dirinya (Grothberg, 1999). Setiap manusia memang membutuhkan resiliensi untuk dapat bangkit dari kesulitan atau kegagalan yang dihadapi dalam hidup. Biasanya kesulitan atau kegagalan memang akan membuat orang menjadi terpuruk hingga mengalami kecemasan dan depresi namun dengan adanya kemampuan resiliensi dalam diri manusia akan membuat manusia melihat makna dari kesulitan atau kegagalan tersebut dan terhindar dari kecemasan dan depresi (Nasution, 2011). Resiliensi merupakan sebuah proses bukan sebuah hasil akhir, yang sekalinya didapatkan dapat diartikan bahwa individu akan selalu resilien. Resiliensi merupakan merupakan proses terwujudnya seluruh potensi yang dimiliki seseorang. Dengan kata lain, resiliensi tidak dapat diartikan sebagai bagian dari kepribadian seseorang yang bersifat static dan dimiliki oleh sekelompok orang tertentu saja (Grothberg, 1999).

Sejalan dengan itu, manusia tentunya membutuhkan faktor-faktor pendukung untuk menumbuhkan resiliensi karena resiliensi tidak didapatkan begitu saja pada diri seseorang. Menurut Reivich dan Shatte (dalam Nasution, 2011) ada tujuh faktor yang berpengaruh dalam kemampuan resiliensi pada diri seseorang yaitu regulasi emosi, impulse control, optimisme, causal analysis, empati, self efficacy, dan reaching out. Salah satu ketrampilan yang penting dibutuhkan seseorang untuk menumbuhkan resiliensi dalam diri adalah adanya ketrampilan regulasi emosi. Menurut Reivich dan Shatte (dalam Nasution, 2011) regulasi emosi penting bagi seseorang untuk dapat mengontrol emosinya apabila menghadapi tekanan. Seseorang yang dapat mengeluarkan ekspresi emosi yang tepat akan membantu menumbuhkan resiliensi pada diri seseorang. Seseorang dengan ketrampilan regulasi emosi dapat tetap tenang walaupun sedang menghadapi tekanan dalam hidup. Penelitian mengenai regulasi emosi menyebutkan bahwa kemampuan mengelola emosi atau regulasi emosi dapat membantu seseorang dalam mengontrol dirinya terutama saat menghadapi masalah dan tekanan sehingga kemampuan mengontrol diri yang baik dapat membantu seseorang mengarahkan perilakunya (Mawardah \& Adiyanti, 2014).

\section{Metode}

Subjek dalam penelitian ini adalah siswa sekolah berasrama SMA " $X$ " di Magelang dengan kriteria siswa masih duduk di kelas 10 dan berusia $14-17$ tahun baik yang berjenis kelamin laki-laki maupun perempuan. Pemilihan subjek pada kriteria tersebut dipilih atas dasar siswasiswa yang duduk di kelas 10 baru saja memulai kehidupannya di sekolah berasrama dan sedang beradaptasi pada lingkungan dan kehidupan sosial yang baru. Regulasi emosi menjadi variabel independen dan resiliensi merupakan variabel dependen. Metode pengumpulan data yang digunakan dalam penelitian ini adalah metode kuantitatif. Alat ukur yang digunakan pada penelitian terdiri dari dua skala yaitu skala resiliensi yang dimodifikasi dari penelitian Ariyani (2012) berdasarkan aspek-aspek resiliensi yang dikemukakan oleh Reivich \& Shatte (2002) dan skala regulasi emosi yang dimodifikasi dari penelitian Nugraheni (2014) berdasarkan aspek-aspek regulasi emosi yang dikemukakan oleh Thompson (1994). Pengambilan data dilakukan dengan menggunakan kuesioner yang disebar dikelas. Metode analisis ynag digunakan adalah metode regresi linier 
sederhana menggunakan software pengolah data SPSS 16.0.

\section{H a s i 1}

Penelitian ini memiliki hipotesis yaitu regulasi emosi berperan terhadap resiliensi pada siswa sekolah berasrama berbasis semi militer. Sebelum proses uji coba skala, aitem di dalam skala divalidasi melalui professional judgement dengan Dosen Pembimbing Skripsi. Uji coba dilakukan di SMA " $X$ " dengan subjek berjumlah 60 siswa. Skala resiliensi memilki 32 aitem dengan koefisien reliabilitas sebesar 0,868. Skal regulasi emosi memiliki 31 aitem dengan koefisien reliabilitas sebesar 0,891.

Hasil perhitungan skor kategorisasi pada tiap-tiap variabel menunjukkan bahwa subjek sebagian besar berada dalam kategori sedang. Pada kategorisasi skor skala resiliensi dapat dilihat terdapat 39 subjek atau sebanyak 43,3\% subjek yang berada pada kategori sedang. Sementara sisanya terdapat 7 subjek $(7,8 \%)$ berada pada kategori sangat rendah, 18 subjek $(20 \%)$ berada pada kategori rendah, 21 subjek (23,3\%) berada pada kategori tinggi, 5 subjek $(5,6 \%)$ berada pada kategori sangat tinggi.

Pada hasil perhitungan kategorisasi skor skala regulasi emosi juga dapat dilihat bahwa sebagian besar sub jek berada pada kategori sedang yaitu sebanyak 35 subjek atau sebanyak 38,9\%. Sementara sisanya terdapat 9 subjek $(10 \%)$ berada pada kategori sangat rendah, 18 subjek $(20 \%)$ berada pada kategori rendah, 25 subjek $(27,8 \%)$ berada pada kategori tinggi, 3 subjek (3,3\%) berada pada kategori sangat tinggi.

Berdasarkan uji asumsi yang dilakukan peneliti meliputi uji normalitas serta uji linearitas disimpulkan bahwa data dalam penelitian ini terdistribusi secara normal dan adanya hubungan yang linear antara variabel tergantung dan variabel terikat. Data terdistribusi secara normal tersebut dibuktikan dengan adanya angka pada persebaran data pada skala resiliensi yang memiliki koefisien signifikansi sebesar 0,678 dan koefisien tes K-SZ sebesar 0,720. Kemudian, persebaran data pada skala regulasi emosi memiliki koefisiensi signifikansi sebesar 0,995 dan koefisien tes K-SZ sebesar 0,417. Adanya hubungan linear dibuktikan dengan linearity sebesar $\mathrm{p}=0,000(\mathrm{p}<0,05)$ dan deviation from linearity sebesar $p=0,347$ $(\mathrm{p}>0,05)$.

Berdasarkan analisis yang dilakukan peneliti, bahwa hipotesis bahwa regulasi emosi berperan terhadap resiliensi pada siswa sekolah berasrama berbasis semi militer dapat diterima. Hal ini dibuktikan dengan hasil uji hipotesis yang dilakukan peneliti dengan teknik regresi linier sederhana yang menunjukkan koefisien regresi sebesar 0,665 dan $\mathrm{R}^{2}$ sebesar 0,466. Hasil tersebut menunjukkan bahwa regulasi emosi berperan terhadap resiliensi sebesar $46,6 \%$.

\section{Diskusi}

Sekolah berasrama SMA " $\mathrm{X}$ " menanamkan pendidikan yang menekankan pada nilai-nilai kejuangan, kebangsaan, dan kebudayaan yang dituangkan ke dalam aspek prestasi akademik, kesamaptaan jasmani, dan kemandirian. Hal ini membuat para siswa di sekolah berasrama SMA " $X$ " harus hidup dengan mandiri selama 24 jam dan dapat bertahan menghadapi tekanan, karena sekolah berasrama ini sendiri merupakan sekolah yang bersifat senioritas dimana adik kelas selain harus menghormati guru tetapi juga harus 
menghormati kakak kelas. Selain itu, sekolah ini juga sangat menjunjung tinggi kedisiplinan siswanya untuk menaati segala peraturan pada sekolah yang sudah secara paten diterapkan. Peraturanperaturan tersebut meliputi peraturan yang bersifat fisik seperti siswa tidak diperbolehkan membawa telepon seluler, tidak boleh membawa makanan berat dari luar, tidak boleh membawa barang pribadi terlalu berlebihan, dan diharuskan menggunakan segala fasilitas yang sudah disediakan sekolah, seperti seragam, tas, peralatan tidur, peralatan makan, dan lainlain. Peraturan lain yang perlu ditaati siswa adalah peraturan yang sudah menjadi budaya pada sekolah berasrama SMA " $X$ " bahwa sekolah berasrama SMA " $\mathrm{X}$ " bersifat senioritas. Hal ini berarti junior harus menghormati pamong (guru) dan juga senior. Siswa junior yaitu kelas 10 harus menghormati kelas 11 dan kelas 12 selain menghormati pamong (guru). Kemudian terdapat juga peraturan seperti siswa diharuskan bangun pagi dan olahraga sesuai jadwal yang sudah ditetapkan, makan pagi, makan siang, dan makan malam juga sesuai jadwal yang sudah ditentukan, serta mengikuti kegiatan lainnya selama 24 jam sesuai jadwal yang sudah ditentukan secara disiplin.

Peraturan seperti yang sudah disebutkan di atas tentunya membuat para siswa harus dapat beradaptasi dengan baik pada segala bentuk peraturan sekolah yang berlaku dan juga harus dapat beradaptasi dengan budaya yang berlaku di SMA " $X$ ". Hal ini lah yang akhirnya menimbulkan masalah pribadi pada individu siswa khusunya kelas 10 karena masih berada dalam tahap adaptasi. Sesuai data yang sudah didapatkan peneliti dari Bimbingan Konseling (BK) SMA " $X$ " bahwa dari tahun ajaran 2010/2011 sampai dengan tahun ajaran
2014/2015 yaitu selama 5 tahun berturutturut persentase siswa yang melakukan konsultasi masalah pribadi selalu lebih banyak daripada masalah sosial, belajar, dan karir. Konsultasi masalah pribadi tersebut menyangkut produktivitas diri, kontrol emosi, ketahanan diri, dan lainlain.

Hal tersebut diperkuat dengan survey yang sudah dilakukan peneliti langsung pada beberapa siswa sekolah berasrama SMA " $X$ " bahwa mereka mereka memang sempat merasa tertekan menghadapi senior mereka dan mengalami sedikit trauma khususnya saat masih kelas 10. Saat kelas 10 itu mereka masih belum terbiasa dengan kehidupan di asrama khusunya dengan peraturanperaturannya karena sangat berbeda dengan kehidupan mereka sebelumnya serta kaget dengan ketentuan yang baru dan harus dijalani dengan mandiri. Seperti yang sudah dipaparkan di atas, diperkuat kembali dengan informasi yang didapatkan dari guru bimbingan konseling bahwa beberapa siswa yang tidak kuat dengan kondisi tekanan tersebut kebanyakan berada pada kelas 10 karena masih awal-awal menghadapi kegiatan dan peraturan di sekolah atau dengan kata lain masih berada pada tahap adaptasi. Beberapa siswa yang tidak kuat tentunya akan bermasalah dengan kehidupan bersaramanya di dalam atau bahkan sampai trauma dan memutuskan untuk keluar dari sekolah (sumber : Bimbingan Konseling (BK) SMA “ $X$ "). Untuk menghindari hal tersebut seharusnya siswa mampu membangkitkan dirinya untuk dapat keluar dari trauma atau tekanan dalam hidup artinya siswa harus memiliki resiliensi yang baik. Resiliensi adalah kapasitas untuk merespon secara sehat dan produktif ketika menghadapi kesulitan atau trauma, dimana hal itu penting untuk mengelola 
tekanan hidup sehari-hari (Reivich \& Shatte, 2002). Siswa tentunya membutuhkan faktor-faktor pendukung untuk menumbuhkan resiliensi karena resiliensi tidak didapatkan begitu saja pada diri seseorang. Penelitian serupa yang dilakukan Tugade \& Fredrickson (2007) menemukan bahwa terdapat hubungan positif yang signifikan antara regulasi emosi dengan resiliensi. Berdasarkan penelitian tersebut peneliti ingin menguji peran regulasi emosi terhadap resiliensi khususnya pada siswa sekolah berasrama SMA " $X$ " yang berbasis semi militer.

Setelah melakukan pengambilan data dan kemudian data tersebut dapat dianalisis dan terlihat bahwa koefisien regresi sebesar 0,665 dan $\mathrm{R}^{2}$ sebesar 0,466. Hasil tersebut menunjukkan bahwa regulasi emosi berperan terhadap resiliensi sebesar $46,6 \%$.

Regulasi emosi mengajarkan bagaimana mengidentifikasi dan menggambarkan emosi, bagaimana untuk mengurangi kerentanan terhadap emosi negatif dan bagaimana meningkatkan emosi positif. Individu yang mampu meregulasi emosi berarti mampu memodifikasi emosi negatif karena pengalaman-pengalaman yang buruk hingga mendapatkan emosi yang positif untuk meraih keseimbangan di dalam emosi, orang yang resilien bisa mengendalikan emosi mereka, terutama dalam menghadapi tantangan atau kesulitan, untuk tetap fokus pada tujuan (Reivich \& Shatte, 2012). Sebuah penelitian oleh Tugade \& Fredrickson (2007) menunjukkan regulasi emosi yang menghasilkan emosi positif akan sangat membantu dalam membangun resiliensi seseorang pada situasi stress atau trauma.

Hasil penelitian ini juga diperkuat oleh beberapa penelitian, salah satu penelitian yang dilakukan oleh Rizki
(2010) menemukan bahwa regulasi emosi mempunyai hubungan yang signifikan dengan resiliensi. Regulasi emosi mempunyai strategi dimana strategi dalam regulasi emosi tersebut dapat membangun resiliensi yang baik. Gross \& John (dalam Eskarita, 2016) menjelaskan 2 strategi yang melibatkan pengalaman emosional dan ekspresi emosional, yaitu (1) Strategi penilaian ulang (Cognitive reappraisal) merupakan bentuk perubahan kognitif individu dengan tujuan untuk mengubah cara berpikir tentang situasi yang berpotensi memunculkan emosi sehingga mampu mengubah dampak emosionalnya. Penilaian ulang merupakan antecedent-focused strategy yang terjadi lebih awal, dan bersifat mengintervensi sebelum kecenderungan respon emosi diaktifkan sehingga dapat mengubah jalannya emosi. Penilaian ulang digunakan untuk mengurangi adanya emosi negatif dan dapat mengurangi aspek pengalaman serta keperilakuan yang negatif. Oleh karena itu, regulasi emosi positif dapat dilihat dari peningkatan penggunaan penilaian ulang. (2) Strategi penekanan (Expressive supression) merupakan bentuk modulasi respon individu dalam mengurangi pengekspresian emosi ketika individu sudah dalam keadaan emosional atau emosi sedang berlangsung. Penekanan merupakan response-focused strategy yang datangnya relatif lambat yaitu terjadi sesudah proses menghasilkan emosi terjadi dan bersifat memodifikasi perilaku dari kecenderungan respon emosi. Penekanan dapat mengurangi ekspresi keperilakuan dari emosi negatif namun juga memiliki efek samping menekan ekspresi emosi positif. Adanya ketidaksesuaian antara pengalaman dalam diri dan ekspresi di luar dapat menciptakan perasaan negatif mengenai diri serta dapat mengasingkan individu dari diri sendiri dan individu lainnya. 
Oleh karena itu, regulasi emosi negatif dapat dilihat dari peningkatan penggunaan penekanan. Selain itu, penelitian Haeussler (2013) menemukan bahwa regulasi emosi dengan resiliensi mempunya hubungan yang positif. Regulasi emosi terutama pada emosi positif dan bukan pada emosi negatif serta strategi pada regulasi emosi yang akan menumbuhkan resiliensi.

\section{Kesimpulan}

Penelitian ini menyimpulkan bahwa regulasi emosi berperan terhadap resiliensi pada siswa sekolah berasrama berbasis militer. Hal tersebut berarti semakin tinggi regulasi emosi yang dimiliki siswa maka akan semakin tinggi pula resiliensi pada siswa. Regulasi emosi berperan sebanyak $46,6 \%$ terhadap resiliensi.

\section{Saran}

Bagi sekolah berasrama SMA " $\mathrm{X}$ ", resiliensi merupakan hal yang sangat dibutuhkan siswa demi kelangsungan hidup secara psikologis di asrama SMA " X" oleh karena itu, peneliti menyarankan kepada sekolah khususnya pada jam pelajaran BK (bimbingan konseling) untuk dapat memberikan pengetahuan seputar proses regulasi emosi sebagai salah satu faktor yang dapat membangun resiliensi. Hal tersebut dapat dilakukan melalui pemberian contoh kasus, konseling kelompok, dan lain-lain.

Bagi penelitian selanjutnya, peneliti dapat menyarankan agar lebih dalam melihat pada strategi regulasi emosi yang diketahui sangat berkontribusi menumbuhkan kemampuan resiliensi. Selain itu, penelitian selanjutnya dapat memperhatikan faktor lain selain regulasi emosi yang juga dimungkinkan dapat menumbuhkan kemampuan resiliensi seperti impulse control, optimisme, causal analysis, empati, self efficacy, dan reaching out. Penyampaian informed consent kepada subjek juga perlu lebih dikuatkan agar subjek penelitian dapat lebih bebas dan jujur dalam pengisian skala sehingga terhindar dari jawaban yang faking.

\section{Kepustakaan}

Ariyani, A. M. (2012). Model bimbingan kelompok berdasarkan pendekatan sistem untuk meningkatkan resiliensi siswa. Tesis. Universitas Negeri Semarang.

Eskarita, S. H. (2016). Peran regulasi emosi dan skema diri terhadap halusinasi auditori pasien skizofrenia paranoid. Tesis. Universitas Gadjah Mada.

Grothberg, E. (1999). Tapping your inner strength. Oakland, CA: New Harbinger Publication, Inc.

Haeussler, S. A. (2013). Emotion regulation and resilience in educational organitations : A case of German school teachers. German: Northumbria University.

Mawardah, M., \& Adiyanti, M. G. (2014). Regulasi emosi dan kelompok teman sebaya. Jurnal Psikologi, 41(1), 60-73.

Nasution, S. M. (2011). Resiliensi: Daya pegas menghadapi trauma kehidupan. Medan: USU Press.

Nugraheni, S. A. (2014). Hubungan antara regulasi emosi dengan intensi remaja berkicau pada media sosial Twitter. Skripsi. Universitas Gadjah Mada.

Reivich, K. \&. Shatte (2002). The resilience factor: 7 essential skills for overcoming life's inevitable obtacles. New York: Broadway Book.

Rizki, B. M. (2010). Hubungan antara strategi regulasi emosi dan faktor 
demografi dengan resiliensi pada perempuan narapidana. Yogyakarta: Universitas Gadjah Mada.

Thompson, R. A. (1994). Emotion regulation: A Theme in search of definition. Monographs of The Society for Research in Child Development, 59(2-3), 25-52. doi: 10.1111/j.15405834.1994.tb01276.x

Tugade, M. M., \& Fredrickson, B. L. (2007). Regulation of positive emotion: Emotion regulation strategies that promote resilience. Journal of Happiness Studies, 311-333.
Ulfiani, T. (2012). Peran boarding school pada SMP IT Abu Bakar Yogyakarta sebagai salah satu upaya penenerapan pendidikan karakter. Skripsi. Universitas Negeri Yogyakarta.

www.sumberdaya.ristekdikti.go.id. (t.t.). Diambil kembali dari http://sumberdaya.ristekdikti.go.id/ wp-content/uploads/2016/02/uunomor-20-tahun-2003-tentangSisdiknas.pdf. 